\title{
Articulating a Contemporary Anarcha-Feminism
}

\author{
Deric Shannon $^{1}$
}

This paper argues that currently we are in need of new articulations of anarcha-feminism. Past currents have been published under "anarcha-feminism" that make it nearly synonymous with various radical feminisms, socialist feminisms, Situationism, and ecofeminisms (often times aside from the anarchist position on the state). However, following developments in both feminist and anarchist theory, it is possible to articulate a general contemporary anarchafeminist theory. This paper, then, mines anarchist and feminist engagements with other theoretical perspectives in a contemporary context to build one such possible articulation of anarcha-feminism. [Article copies available for a fee from The Transformative Studies Institute.E-mail address: journal@transformativestudies.org Website: http://www.transformativestudies.org (C2009 by The Transformative Studies Institute. All rights reserved.]

KEYWORDS: Anarchism, Feminism, Radicalism, Queer Theory, PostColonialism, Post-Strucuralism.

"...even a lot of folks in the Black Liberation struggle or the Anarchist People of Color folks who I work with... When we begin to interact with other movements, we begin to learn, as we always hope that people will learn from ours." --Ashanti Alston (Compassionate Living Project 2007)

In this excerpt from a presentation given at the United Poultry Concerns 7th annual conference, former Black Panther and anarchist, Ashanti Als-

\footnotetext{
${ }^{1}$ Deric Shannon is a long time social anarchist activist with roots in groups like AntiRacist Action and Food Not Bombs. He is an editor of Contemporary Anarchist Studies (Routledge, Spring '09), An Economy of Sustainability: Anarchist Economics (AK Press, Forthcoming), the author of the entry for "Anarchism, Communism, and Socialism" in the Encyclopedia of Modern Revolutions (James DeFronzo, ed.), and a number of book chapters and journal articles, typically on radical political thought. He lives in Connecticut where he works with Hartford Food Not Bombs, Queers without Borders, and the Hog River Collective. Address correspondence to: Professor Deric Shannon, University of Connecticut, 59 Glenwood St., Manchester, CT 06040; tel: 765.717.4490; e-mail: deric.shannon@uconn.edu.
} 